\title{
Ethical and Socially Responsible Practices among SME Owner-Managers: Proposing a Multi-Ethnic Assessment
}

\author{
Noor Hazlina Ahmad ${ }^{1}$, Azlan Amran ${ }^{2}$ and Hasliza Abdul Halim ${ }^{1}$ \\ ${ }^{1}$ School of Management, Universiti Sains Malaysia, Malaysia \\ ${ }^{2}$ Graduate School of Business, Universiti Sains Malaysia, Malaysia
}

\begin{abstract}
Building on the stakeholder theory, this paper proposes a conceptual framework that looks into the effects of ethical and socially responsible practices on the financial and non-financial performance of SME in Malaysia. This paper argues that ethical and socially responsible commercial practices are seen critical in order to build a strong ground for harmonious business dealings among the multiracial community in Malaysia which could subsequently affect the overall performance of the SMEs. The varying commercial interests, distinct cultural perspectives, and historically distinct skill and trades could provide a rich perceptual framework for understanding the ethical and socially responsible practices in commercial settings. Even though it has been reported that there is minimal cultural distance between Malays, Chinese and Indians, it is likely that the various challenges faced in the commercial settings have some bearings on their perception of ethics and social responsibility. It is envisaged that this research will provide a better insight into the intercultural variation in regards to values, ethical and socially responsible practices among entrepreneurs in Malaysia and promote a better understanding of the linkage of personal values held by three racial groups in Malaysia and their business practices.
\end{abstract}

Keywords: Ethical Practices; Socially Responsible Practices; SME

\section{Introduction}

There has been a prolific discussion in regards to the effects of national culture on business ethics as well as entrepreneurial behaviours. Some scholars seeking to move beyond national cultures suggest focusing on more fine-grained variations within a nation. In the context of multicultural country such as Malaysia, the intercultural differences provide an important reflection on the existence and range of values and beliefs within a nation. Indeed, Hofstede cautioned that there may be linguistic, regional, tribal, ethnic, or caste cleavages within nations that may sometimes make national data nonrepresentative for the nation as a whole (Hofstede, 1980, p. 23). Even though some researchers argue that Malaysians have streamlined their values under a shared wider socio-cultural environment (Yusof \& Amin, 1999), it is believed that there still exist some values among the three major racial groups (i.e., Malay, Chinese, and Indians) that can be markedly different from the dominant culture, especially in business practices. This is because in Malaysia, the ethnic divisions tend to be reinforced by religious, cultural, linguistic, and economic divisions (Zabid, 2003). Since values affect

Copyright (c) 2012 Noor Hazlina Ahmad, Azlan Amran and Hasliza Abdul Halim. This is an open access article distributed under the Creative Commons Attribution License unported 3.0, which permits unrestricted use, distribution, and reproduction in any medium, provided that original work is properly cited. Contact author: Noor Hazlina Ahmad E-mail: hazlina@usm.my 
the way people think and behave, the personal/cultural values of the entrepreneurs may also influence their perception of the prevalence of ethical and socially responsible practices in the commercial setting. According to Fritzche (1995), behaviour is a result of one's values and attitudes.

There are three important reasons as to why these practices in smaller firms should be examined more closely. Firstly, there is a large disparity in the number of studies of ethical and social responsibility issues between large firms and small firms (Quinn, 1997). To date, work on ethics and social responsibility has been largely concentrated on large firms (Morris, Schindehutte, Walton, \& Allen, 2002) particularly in the context of Malaysia (see, for example, Rashid \& Ibrahim, 2002; Thompson \& Zakaria, 2004). As noted by Spence and Rutherfoord (2001), the size of firms is a significant differentiator for ethical issues whereby such issues identified in the larger firms do not reflect what is actually happening in smaller firms. Secondly, smaller firms have strong interconnectedness with the local community in which they operate in (Gibb, 2005). Often, they deal with the same cohort of customers who reside in their local areas (Spence, 1999) and the conduct of ethical and socially responsible business is an important factor in creating a harmonious "businesscustomer" relationship in the local community. Thirdly, there is an increasing awareness about ethics and social responsibility, thereby leading societies to disapprove firms that are found to be ethically ill and irresponsible. In light of the notion, "good ethics is good for business" (Zairi \& Peter, 2002), failure to adhere to such practices would have an adverse impact on business. Similarly, Vyakarnam, Bailey, Myers, and Burnett (1997) argue that ethical behaviours is one of the reasons why a firm is able to stay longer in business.

It has been observed that the agenda of ethics and social responsibility in developing countries (e.g., Malaysia) lags behind developed countries (e.g., Australia). For instance, the 2009 Corruption Perception Index (CPI) reported that, of the 180 countries studied, Malaysia was ranked 56 th - way behind other Asian countries such as Singapore, Hong Kong, Japan, and Taiwan (Transparency International, 2009). Even though the CPI report is not limited to small businesses, it is a reflection of the general ethical standards in these countries. With regards to social responsibility, the Council of Small Business Organisations of Australia (2000) reported that two-thirds of the small businesses surveyed (from a sample of 9000) revealed strong socially responsible behaviours especially in terms of providing support for the local community. More recently, Madden, Scaife, and Crissman (2006, p. 57) found that "there was a genuine enthusiasm for the notion of corporate social responsibility which was viewed as duty" among the Australian SMEs. In contrast, it was observed that the awareness in regards to ethics and social responsibility among smaller business is still relatively lacking in Malaysia. This is because the focus on such issues in Malaysia is often directed to large firms compared to smaller firms (see, for example, Rashid \& Ibrahim, 2002; Thompson \& Zakaria, 2004).

Notwithstanding this, the issues of ethics and social responsibility in small firms may be to some extent different from their larger counterparts due the nature and characteristics of these firms. Small firms are, by nature, independent and self-managed (Spence \& Lozano, 2000). Presumably, the key aspects of ethics would revolve around the personal values and beliefs of the owners themselves, rather than governed by the ethical codes of conduct as in larger firms. 'Multitasking' is another key criterion of small businesses (Spence, 1999).

The variety of tasks facing small business owners may leave them with less time to consider ethics in their daily business management. In addition, according to Vyakarnam (1997, p.1627), "what constitute personal and business ethics are probably 
closer in situations where the owner is also the manager in a business. Relatively speaking, recession has greater impact on small firms compared to larger ones, making business survival one of the top agenda among smaller firms". Given these constraints facing small business owners, it is therefore crucial to closely examine the extent to which ethical and social responsibility considerations is applicable in smaller firms.

In surmise, the purpose of this paper is to address these issues (i.e., ethics and social responsibility in SMEs) by advancing a conceptual framework that links the personal value of SME owner-managers, the ethical and socially responsible practices, and business performance. This paper commences with the discussion on the relevant literature followed by conceptual framework, in the course of which a number of propositions are formulated. Next, brief details on method, sample and measures to be utilized for subsequent data collection are presented. Finally, this paper concludes with discussion of the study and their implications.

\section{Country Context: Malaysia - A Multicultural Society}

Malaysia is a multi-ethnic country of 27 million people with Malays forming the predominant ethnic group, followed by Chinese and Indians. Owing to its multiracial composition, many have argued that Malaysians hold divergent cultural values, even though there is evidence to show that Malaysians in general share similar cultural values (i.e., collectivism and a relationship orientation). The only difference found among the three races was in terms of religiosity, with Malays holding religious beliefs to be far more important than their Chinese and Indian counterparts (Abdullah \& Lim, 2001). However, it is believed that diverse communities and ethic groups within a nation, with their varying commercial interests, distinct cultural perspectives, and historically distinct skill and trades provide a rich perceptual framework for understanding the ethical and socially responsible practices in commercial settings.

Delving into the effect of personal values is one of the mechanisms to understand the variations in how Malays, Chinese, and Indians perceived ethical and socially responsible practices in business setting. This follows Zabid and Ho's (2003) contention that personal or cultural values held by an individual could lead to differing views on what is considered right or wrong, ethical or unethical, and socially responsible or otherwise. Interestingly, an investigation of cultural values in Malaysia by Fontaine and Richardson (2005), using Schwartz's cultural values suggests that Malays, Chinese, and Indians share similar cultural values. However, Lim (2001) argues that the increased pressure from economic activities, associated with increased attention by the government on economic development, could result in changes in terms of cultural values. Therefore, even though it has been reported that there is minimal cultural distance between Malays, Chinese and Indians, it is likely that the various challenges faced in the commercial settings have some bearings on their perception of ethics and social responsibility.

\section{Small and Medium-Sized Enterprises (SMEs) in Malaysia}

The main reason for the focus on Malaysian SMEs is based on the importance of SMEs to Malaysia economy. SMEs have been acknowledged as the strategic thrust in Malaysia economy based on various reports of government agencies (SME Annual Report 2005, 2006: 9th Malaysia Plan, 2006; Third Industrial Master Plan (IMP3) 2006 - 2020, 2006). Table 1 presents the definition of SME provided by SMECorp, Malaysia. Table 2 tabulates the Distributions of SMEs based on The Census of Establishments and Enterprises 2005 by The Department of Statistics. 
Table 1: Definition of SMEs in Malaysia

\begin{tabular}{|c|c|c|c|}
\hline & Micro-enterprise & Small enterprise & Medium enterprise \\
\hline $\begin{array}{l}\text { Manufacturing, } \\
\text { Manufacturing- } \\
\text { Related Services and } \\
\text { Agro-based } \\
\text { industries }\end{array}$ & $\begin{array}{l}\text { Sales turnover of } \\
\text { less than } \\
\text { RM250,000 OR full } \\
\text { time employees less } \\
\text { than } 5\end{array}$ & $\begin{array}{l}\text { Sales turnover } \\
\text { between RM250,000 } \\
\text { and less than RM10 } \\
\text { million OR full time } \\
\text { employees between } \\
5 \text { and } 50\end{array}$ & $\begin{array}{l}\text { Sales turnover } \\
\text { between RM10 } \\
\text { million and RM25 } \\
\text { million OR full time } \\
\text { employees between } \\
51 \text { and } 150\end{array}$ \\
\hline $\begin{array}{l}\text { Services, Primary } \\
\text { Agriculture and } \\
\text { Information \& } \\
\text { Communication } \\
\text { Technology (ICT) }\end{array}$ & $\begin{array}{l}\text { Sales turnover of } \\
\text { less than } \\
\text { RM200,000 OR full } \\
\text { time employees less } \\
\text { than } 5\end{array}$ & $\begin{array}{l}\text { Sales turnover } \\
\text { between RM200,000 } \\
\text { and less than RM1 } \\
\text { million OR full time } \\
\text { employees between } \\
5 \text { and } 19\end{array}$ & $\begin{array}{l}\text { Sales turnover } \\
\text { between RM1 } \\
\text { million and RM5 } \\
\text { million OR full time } \\
\text { employees between } \\
20 \text { and } 50\end{array}$ \\
\hline
\end{tabular}

Table 2: Distributions of SMEs based on the Census of Establishments and Enterprises 2005 by the Department of Statistics

\begin{tabular}{|l|c|c|c|c|}
\hline Sector & Establishments & SMEs & $\begin{array}{c}\text { Percentage of } \\
\text { SMEs }\end{array}$ & $\begin{array}{c}\text { Percentage of } \\
\text { Structure }\end{array}$ \\
\hline $\begin{array}{l}\text { Total } \\
\text { Manufacturing }\end{array}$ & 39,219 & 37,866 & 96.6 & 7.3 \\
\hline Services & 119,980 & 118,662 & 98.9 & 23.0 \\
\hline $\begin{array}{l}\text { Retail, } \\
\text { Wholesale and } \\
\text { Restaurants }\end{array}$ & 312,245 & 311,234 & 99.7 & 60.2 \\
\hline Finance & 19,291 & 19,108 & 99.1 & 3.7 \\
\hline Total Services & 451,516 & 449,004 & 99.4 & 86.9 \\
\hline $\begin{array}{l}\text { Total } \\
\text { Agriculture }\end{array}$ & 32,397 & 29,985 & 92.6 & 5.8 \\
\hline Overall Total & 523,132 & 516,855 & 98.8 & 100 \\
\hline
\end{tabular}

Abdullah and Beal (2003) highlight several important contributions of SMEs in this regard. Firstly, because they are labourintensive, SMEs create employment opportunities. Secondly, SMEs enhance regional development and create more equitable income distribution due to their location and ongoing expansion throughout the broader community. Thirdly, SMEs play a vital complementary role in relation to larger firms. In many cases, large firms depend on SMEs as suppliers and distributors. For example, many SMEs in Malaysia supply component parts, tools, and equipment to larger manufacturing firms. Large firms also rely on SMEs for the distribution of their products to the consumer. Fourthly, SMEs serve as a training ground for developing the skills of workers and entrepreneurs. Finally, the presence of SMEs curbs the monopoly power of larger firms and provides the structure of the economy with greater flexibility. Thus, a country can reduce its vulnerability to financial crises by strengthening its SMEs and ensuring their success. 


\section{Ethics and Social Responsibility: Mechanism to Promote Harmonious Business and Societal Relationship}

Zsolnai's (2004) suggests that "ethics is not a luxury of advanced economies, it is an indispensable means to foster economic development" (p.57), therefore, it is crucial for the small businesses in developing economies to understand the importance of such constructs in their daily business activities, especially in the context of Malaysia. Also, given the possible existence of intercultural variation in regards to personal values of the entrepreneurs (i.e., Malay, Chinese, and Indians) that may affect ethical and socially responsible practices, this study aims at providing some answers to these questions: "To what extent do personal values of SME entrepreneurs in Malaysia influence the perception of and practice ethics and social responsibility?" and also "to what extend do these practices influence business success?"

Various studies have shown that ethical considerations are important for business (Hornsby, Kuratko, Naffziger, LaFollete, \& Hodgetts, 1994; Spence, 1999; Spence \& Lozano, 2000; Quinn, 1997). Ethical practices within a commercial context make claims about 'what ought to be done or what ought not to be done' in managing a business (Kuratko, Hornsby, \& Naffziger, 1997). Ethics as a code of conduct in larger firms has been the centre of attention in business ethics research. With a view that ethical practices should be the guiding principle for all businesses, large or small, studies investigating ethics in smaller firms have started to gain momentum. One such study conducted by Vyakarnam et al. (1997) found that ethical issues experienced by smaller firms in the UK revolved around the issues of conflict of interest among the stakeholders, protection of knowledge and information, legal and moral obligation, and personal versus business decisions. Also using a dilemma-based approach, Spence and Rutherfoord (2001) identified that there are four major dilemmas facing small business owners including profit maximisation, subsistence priority, enlightened selfinterest, and social priority.

Closely related to ethical practices is social responsibility. Fülöp et al. (2000)'s define social responsibility as "the positive activities a company undertakes in the society in which it operates" including responsibility towards customers, employees and the public. When the concept was first developed more than twenty years ago, organisations found it difficult to operationalise it in their business practices, as it required sacrifices to be made on the financial level. However, recently, organisations' leaders have started to acknowledge the importance of being socially responsible in business affairs. For example, the authors found that there is a growing commitment to social responsibility among smaller firms, which is comparable to that of larger firms. Specifically, they found that small firms have demonstrated willingness to make arrangements to meet the requirements of social responsibility especially to their customers, their employees, and the public.

Through the business lens, ethics and social responsibility practices is said to benefit the entrepreneurs financially in the long run. According to Goll and Rasheed (2004), in fast-changing and unpredictable environments, socially responsible behaviours help organisations to gain support from various external stakeholder groups. Such behaviours provide them with some protection from unpredictability they face. It is also important to note that an organisation's image and reputation may be influenced by the good ethical conduct it portrays to the public (Jones, 2000). Taken together, the benefits of ethical and socially responsible practices enable competitive advantage to be attained as a firm distinguishes itself from its competitors.

Beyond commercial perspective, such fine gestures demonstrated by the entrepreneurs are seen as mechanism to promote harmonious business and societal 
relationships. In particular it could enhance trust, cooperation, and tolerance among the three diverse racial groups given that one could understand why others behave in the way they do. The three elements are intrinsically important because they are core characteristics that positively affect the emotional and interpersonal aspects of the work and life relationships. As such ethics and social responsibility inquiry deserve more attention.

\section{Proposed Conceptual Framework}

The preceding discussion that conjectures strong linkages between ethical and social practices to business performance and harmonious societal relationship augurs well with the stakeholder theory, both from instrumental and normative perspective. According to Branco and Rodrigues (2007), the instrumental approach to stakeholder theory views maximization of company's wealth can be attained by means of satisfying stakeholders' interests, whereas the fundamental assumption of normative approach to stakeholder theory suggests that "a company should behave in a socially responsible manner because it is morally correct to do so" (Branco \& Rodrigues, 2007, pp. 13). Based on this underpinning theory, conceptual framework is advanced for further investigation. Personal values of the SME entrepreneurs from the three main races (i.e., Malay, Chinese, and India) in Malaysia are treated as the independent variable. Perceived role of ethics and social responsibility as well as ethical and socially responsible practices in business are mediating variables. The dependent variable is business performance in the context of SME. The proposed relationships among these variables are depicted in Figure 1.

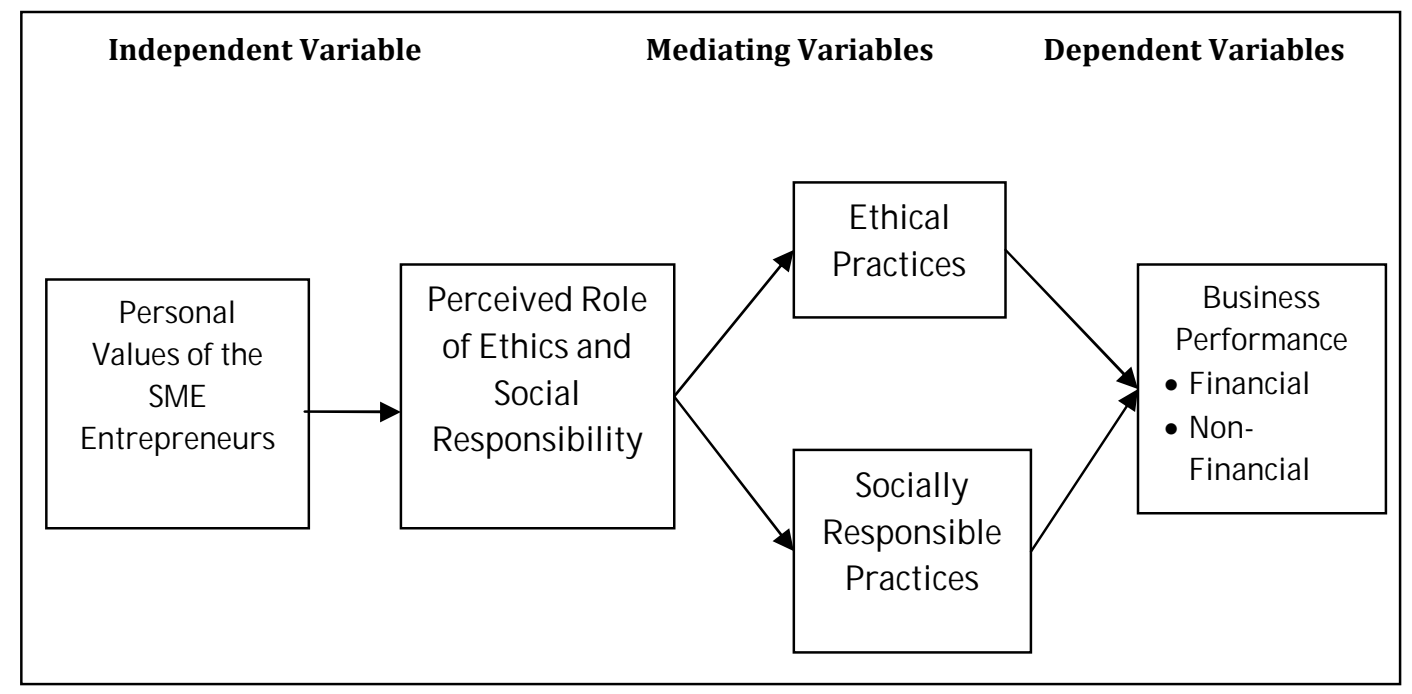

Fig 1. Conceptual Framework

\section{Propositions:}

P1: The personal values of SME entrepreneurs' are positively associated with perceived role of ethics and social responsibility.
P2: Perceived role of ethics and social responsibility is positively associated with ethical and socially responsible practices. 
P3: Ethical practices and socially responsible practices are positively associated with business performance.

P4: Perceived role of ethics and social responsibility will significantly mediates the relationship between personal values and ethical and socially responsible practices.

P5: Ethical and socially responsible practices will significantly mediates the relationship between perceived role of ethics and social responsibility and business performance

\section{Discussion and Conclusion}

It is envisaged that this research will set a stage to:

1. provide a better insight into the intercultural variation in regards to values, ethical and socially responsible practices among entrepreneurs in Malaysia.

2. promote a better understanding of the linkage of personal values held by three racial groups in Malaysia and their business practices.

3. identify the ethical and socially responsible practices perceived important by SME entrepreneurs

4. validate if such ethical and socially responsible practices do influence business performance (i.e., financial and non-financial).

5. benefit the society in a way that it will promote a strong ground for harmonious business dealings and communal relationship within the multiracial society given that this study will enlighten the related parties on the similarities and differences among them.

The value of this study lies in its effort to provide an informed understanding of the ethical and socially responsible practices in smaller firms, particularly in the context of
Malaysia. The identification of such "noble" practices would signal an important message regarding the prevalence of such practices, particularly in smaller firms, because of their strong interconnectedness with employees, customers, and local community. Ethical and socially responsible considerations are seen pivotal given that harmonious "businessbusiness", "customer-business" and "community-business" relationships could bolster firm performance and to a larger extent, promote communal unity that is built upon trust, respect, and integrity. Importantly, this study would alert Malaysian society and entrepreneurs in particular, of the prevailing similarities and differences in the way in which each ethnic group views ethics and social responsibility. This is because misunderstandings and prejudice derive from the lack of trust may result in conflict that sets each group apart.

Also, in view of 'good ethics is good for business', it is assumed that failure to adhere to such practices will have major implication to the business well-being. The good example (in terms of the demonstration of ethical and socially responsible practices) set by the smaller firms may influence the broader trading environment to improve standards of behaviour and integrity in business. The awareness of ethical business practices among smaller firms could also furnish a healthier economy (Bishop, 1992), as they make up more than $80 \%$ of all establishments in most countries.

Above all, business practitioners should realise that ethics, social responsibility, and profit making can go hand in hand; they are not conflicting agendas. Therefore, a challenge for entrepreneurship educators and policy makers is to recognise the distinctive aspect of these practices in SMEs and not to treat the issue of ethical and social responsibility through the lens of large firms' corporate policies but as means for creating small firms' competitive advantage. As argued by Hatten (2006), ethical and social responsibility issues in smaller firms should go hand in hand with the strategic planning 
of the firms because the entrepreneurs' decisions of "what to do and how to go about doing it" are largely influenced by their ethical and socially responsible values. Training programs that could portray the relationships among strategic planning, ethics, and social responsibility of the entrepreneurs is of great value.

\section{References}

Abdullah, A. \& Lim, L. (2001). 'Cultural Dimensions of Anglos, Australians, and Malaysians,' Malaysian Management Review, 36(2), 1-17.

Abdullah, M. A. \& Beal, T. (2003). 'The Strategic Contributions of Small and Medium Enterprises to the Economics of Japan and Malaysia: Some Comparative Lessons for Malaysian Smes,' The Seventh International Conference on Global Business and Economic Development, Strategies for Sustainable Business Responses to Regional Demands and Global Opportunities, Bangkok, Thailand, 1337-1354.

Branco, M. C. \& Rodrigues, L. L. (2007). "Positioning Stakeholder Theory within the Debate on Corporate Social Responsibility," Electronic Journal of Business Ethics and Organization Studies, 12 (1), 5-15.

Council of Small Business Organisations of Australia. (2000). The Spirit of EnterpriseNational Survey of Small Business Community Involvement, COSBOA, Canberra.

Fontaine, R. \& Richardson, S. (2005). "Cultural Values in Malaysia: Chinese, Malays and Indians Compared," Cross Cultural Management: an International Journal, 12(4), 63-77.

Fritzche, D. J. (1995). "Personal Values: Potential Keys to Ethical Decision Making," Journal of Business Ethics, 14 (11), 909-922

Fülöp, G., Hisrich, R. D. \& Szegedi, K. (2000). "Business Ethics and Social Responsibility in
Transition Economies," The Journal of Management Development, 19(1), 5-31.

Gibb, A. A. (2005). 'The Entrepreneur as the Core Competence of the Firm: Implication for Management Educators,' Entrepreneurship, Innovation, and Small Business Network, Issue 2.

Hofstede, G. H. (1980). Culture's Consequences: International Differences in Work-Related Values, Beverly Hills: Sage Publications.

Hornsby, J. S., Kuratko, D. F., Naffziger, D. W., Lafollette, W. R. \& Hodgetts, R. M. (1994). "The Ethical Perceptions of Small Business Owners: a Factor Analysis Study," Journal of Small Business Management, 32(4), 9-16.

Kuratko, D. F., Hornsby, J. S. \& Naffziger, D. W. (1997). 'An Examination of Owner's Goals in Sustaining Entrepreneurship,' Journal of Small Business Management, 35(1), 24-33.

Lim, L. (2001). "Work-Related Values of Malays and Chinese Malaysians," International Journal of Cross Cultural Management, 1(2), 209-226.

Luken, R. \& Stares, R. (2005). "Small Business Responsibility in Developing Countries: a Threat or an Opportunity?," Business Strategy and the Environment, 14, 38-53.

Madden, K., Scaife, W. \& Crissman, K. (2006). "How and Why Small to Medium Size Enterprises (Smes) Engage with Their Communities: an Australian Study," International Journal of Nonprofit and Voluntary Sector Marketing, 11(1), 49-60.

Morris, M. H., Schindehutte, M., Walton, J. \& Allen, J. (2002). "The Ethical Context of Entrepreneurship: Proposing and Testing a Developmental Framework," Journal of Business Ethics, 40(4), 331-361.

Quinn, J. J. (1997). "Personal Ethics and Business Ethics: the Ethical Attitudes of 
Owner/ Managers of Small Business," Journal of Business Ethics, 16, 119-127.

Rashid, M. Z. \& Ho, J. A. (2003). "Perceptions of Business Ethics in a Multicultural Community: the Case of Malaysia," Journal of Business Ethics, 43 (1-2), 75-87.

Rashid, M. Z. \& Ibrahim, S. (2002). "Executive and Management Attitudes Towards Corporate Social Responsibility in Malaysia," Corporate Governance, 2 (4), 10-16.

Román, S. \& Munuera, J. L. (2005). "Determinants and Consequences of Ethical Behaviour: an Empirical Study of Salespeople," European Journal of Marketing, 39(5/6), 473 - 495.

Spence, L. J. (1999). "Does Size Matter? the State of the Art in Small Business Ethics Business Ethics," A European Review, 8 (3), $163-174$.

Spence, L. J. \& Lozano, J. F. (2000). "Communicating About Ethics with Small Firms: Experiences from the U.K. and Spain," Journal of Business Ethics, 27: 43-53.

Spence, L. J. \& Rutherfoord, R. (2001). “Social Responsibility, Profit Maximisation and the Small Firm Owner-Manager," Journal of Small Business and Enterprise Development, 8(2), 126-139.

Thompson, P. \& Zakaria, Z. (2004). "Corporate Social Responsibility Reporting in Malaysia," Progress and Prospects, The Journal of Corporate Citizenship, 13, 125-137.

Transparency International. (2009). "2009 Corruption Perceptions Index," [Online], [Retrieved June 20, 2010], Http:/ / Www.Transparency.Org/ Policy_Rese arch/Surveys_Indices/Cpi/ 2009
Ushedo, B. O. \& Ehiri, J. E. (2006). "Ethical Challenges in Ecological Policy: Global Thinking and Local Action," Management of Environmental Quality: an International Journal, 17(1), 31-42.

Vyakarnam, S., Bailey, A., Myers, A. \& Burnett, D. (1997). "Towards an Understanding of Ethical Behaviour in Small Firms," Journal of Business Ethics, 16, 1625-1636.

Yusof, S. A. \& Amin, R. M. (1999). "Admired Values: the Case of Teenagers in Malaysia," International Journal of Social Economics, 26(5/6), 802-810.

Zairi, M. \& Peters, J. (2002). "The Impact of Social Responsibility on Business Performance," Managerial Auditing Journal, 17(4), 174-178.

Zsolnai, L. (2004). "Honesty and Trust in Economic Relationships," Management Research News, 27, 57-62. 